DOI: 10.2478 /ausp-2020-0025

\title{
Social Meanings of the Hungarian Politeness Marker Tetszik in Doctor-Patient Communication $^{1}$
}

\author{
Ágnes KUNA \\ Department of Applied Linguistics and Phonetics \\ Eötvös Loránd University \\ kuna.agnes@btk.elte.hu \\ Ágnes DOMONKOSI \\ Department of Hungarian Linguistics \\ Eszterházy Károly University \\ domonkosi.agnes@uni-eszterhazy.hu
}

\begin{abstract}
The paper explores how the politeness marker tetszik is used in Hungarian and how its functions are evaluated by the participants of doctorpatient communication. The possible functions of tetszik are investigated on the basis of questionnaires filled in by 50 patients and 50 GPs. Data about the social meanings of tetszik are presented with regard to the following: proportions of the use of tetszik in doctor-patient communication; metapragmatic evaluations and attitudes to the use of tetszik by doctors and patients; probable strategies underlying its use. Based on the data, we conclude that the use of the politeness marker tetszik is prototypically respectful while conveying familiarity and friendliness, with the age, gender, and relative status of the interlocutors also taken into consideration.
\end{abstract}

Keywords: doctor-patient interaction, politeness marker, V-forms of address, social meaning, speaker's strategies

\section{Introduction}

A peculiar structure among Hungarian address conventions involves the use of the auxiliary tetszik 'to please' followed by an infinitive. In Hungarian, the dichotomy

1 This research was supported by the János Bolyai Research Scholarship of the Hungarian Academy of Sciences (Á. D., Á. K.), by the ÚNKP-20-5-ELTE-484 (Á. K.) and ÚNKP-19-4-EKE-1 (Á. D.) New National Excellence Program of the National Research, and also by the grant of NKFIH K Nr. 129040 (Á. D., Á. K.). 
between the T- and V-forms ${ }^{2}$ of address (Brown-Gilman 1960) is complicated by the fact that there are several ways to express $\mathrm{V}$. The construction involving tetszik can complement various V-forms indicating politeness, while if it is used in order to avoid V-pronouns, it can occur independently as a form of V-address as well (Domonkosi 2002, 2010, 2018; Domonkosi-Kuna 2015a, 2015b).

The aim of this paper is to discuss the use of tetszik and the evaluation of its social meanings by participants in doctor-patient communication. The empirical data of the research was collected via questionnaires filled in by 50 patients and 50 GPs. Our research was motivated by the assumption that doctor-patient communication, with its basically hierarchical and asymmetric character, was a proper testbed for revealing various functions of tetszik through gender and age relations and the diversity of communicative situations.

After the present introductory section (1), the paper introduces the theoretical background of the analysis (2). This is followed by a discussion of data collecting methods (3). Section 4 gives an overview of the results of previous investigations reported in the literature and introduces our research questions about the use of tetszik as a politeness marker in doctor-patient interaction. The social meanings of tetszik are presented with regard to the following aspects: proportions of the use of tetszik in doctor-patient communication, metapragmatic evaluations of its social meanings by doctors and patients, and the strategies that may motivate its use (5). Finally, the paper concludes with a summary of our research findings (6).

\section{Theoretical background}

In sociolinguistic interpretations of the social meanings of address forms, traditional accounts focused on the dimensions of power and solidarity (Brown-Gilman 1960, Brown-Ford 1964, Ervin-Tripp 1972, Braun 1988). However, more recent analyses have foregrounded new criteria as well. Exploring the functioning of forms of address, Clyne, Norrby, and Warren (2009: 29-30) also rely on Svennevig's model of the dimensions of social distance. The latter approach interprets social distance as a multi-dimensional phenomenon shaped jointly by the dimensions of solidarity, familiarity, and affect (Svennevig 1999: 33-35). The utility of this model for interpreting forms of address derives primarily from the fact that while all three factors have a scalar structure, their relevance in construing particular situations may vary (Clyne-Norrby-Warren 2009: 28). Therefore, in our interpretations of the varied functions and socio-cultural roles of Hungarian forms of address, we take into account the multi-dimensional character of social distance.

2 Following Brown and Gilman's (1960: 256-276) dichotomous view of address introduced in their classic paper, $\mathrm{T}$ stands for informal while $\mathrm{V}$ for formal, official, more distanced address. 
Regarding sociolinguistic approaches to style, our work is informed primarily by those in which style is interpreted as part of self-representation (Eckert-Rickford 2001, Schilling-Estes 2004). However, we do not regard style as simply a matter of speaker design (Schilling-Estes 2004: 388) but rather as the construal of social meanings in context, which consequently involves the construal and "design" of the entire situation, including the identities and roles of both speaker and listener (Coupland 2007: 80). In line with interactional stylistics, we also investigate the reasons behind choices in construals of social meaning; in other words, we describe choices of forms of address as aspects of strategies aimed at the dynamic construal of the speech situation. Our perspective highlights the functioning of language as socio-cultural praxis geared towards meaning making and interprets address practices as instruments of construing social reality (Norrby-Wide 2015, Norrby et al. 2015, Wide et al. 2019). Under the assumptions of social constructivism, social relations are linguistically negotiable (cf. Bartha-Hámori 2010), and the practice of using address forms may crucially contribute to the construal of various types of interpersonal relations.

A variety of linguistic patterns represent ways of construing the speaker's relation to the listener. The contribution of address forms to this process is both critically important and encoded in cultural tradition. Basically, the division between T- and V-forms is derived from the dichotomy of formality vs. informality. However, the variety and use of Hungarian address forms suggest that further aspects should also be considered if the aim is to specify the social meaning of tetszik in sufficient detail. Mapping the usage and roles of tetszik thus requires, and informs, the inclusion of a number of relevant subdomains of the speech situation in the model.

If the situation is studied on the axis of formal vs. informal, then medical communication is one of the most formal situations. Previous studies on T- and V-distributions also arrived at similar conclusions (Domonkosi 2002: 147). Doctorpatient consultations are situations in which T-forms are the least likely to occur, even less than in official administrative situations. However, the types of V-forms used in this situation suggest that in and by itself the formal vs. informal axis is not sufficient for describing the relationship between discourse participants (CsiszárikDomonkosi 2018).

Besides the concept of formality vs. informality, the relationship between speakers and the construal of a situation has also been studied from the viewpoint of familiarity, distance, deference, camaraderie, and involvement (Clyne-NorrbyWarren 2009). Bartha and Hámori (2010), for example, conduct their analysis along the axes of involvement vs. distance, solidarity vs. power, convergence vs. divergence, and directness vs. indirectness. In the present paper, we attempt to integrate these insights into our interpretation of the strategies that motivate the use of tetszik. 


\section{Data and methodology}

The research reported in the paper forms part of a comprehensive, methodologically complex study of doctor-patient communication, which started in 2012 and is still in progress (Kuna-Hámori 2019, Kuna 2020). The present analysis is based on data elicited by way of a questionnaire study between 2013 and 2015 (see Appendix). Notably, the compilation of questions was informed by previous data derived from participant observation at four male GP surgeries in the autumn of 2012 (for details, see Kuna-Kaló 2014, Kuna 2016). The data comprising more than 400 doctor-patient encounters was analysed for characteristic linguistic patterns. One striking feature was the high frequency of tetszik in doctors' speech, even in cases where both the doctor and the patient were young. In fact, the choice of this form appeared to be dominant in the communicative behaviour of certain GPs. In view of the controversial attitudes of Hungarian speakers to tetszik, we decided to carry out a questionnaire study to learn more about this trend. While compiling questions for the questionnaire, we made use of real-life dialogues that had been recorded during consulting hours. The questionnaire was prepared in two versions, with parallel questions tailored to the different roles of doctors and patients. The questionnaires were filled in by 50 doctors and 50 patients in the autumn of 2013. Due to its limited size, the material thus gathered fails to support a comprehensive quantitative account of the distribution of tetszik along social parameters (e.g. gender, age, place of residence). However, it does give a clear indication of the proportions and underlying strategies of using tetszik in doctorpatient communication.

Questionnaire study as a method has been standardly adopted in investigations into forms of address ever since the emergence of this field of research (BrownGilman, 1960, Braun 1988, Clyne-Norrby-Warren 2009, Norrby-Wide 2015). At the same time, when it comes to interpreting the results, we are mindful of the fact that this method does not produce an accurate picture of language use per se. Rather, the results reflect speakers' perceptions about it and the stereotypical social indexical values associated with particular forms (Ervin-Tripp 1972: 219, Agha 2007: 282).

On the one hand, we compiled the questionnaire in an attempt to accommodate tetszik structures into the Hungarian address system. Accordingly, we aimed to find out about this construction's frequency of use and basic differences between how doctors and patients adopt it. On the other hand, we attached importance to asking open questions about the speakers' spontaneous metapragmatic evaluations as well. We consistently asked for reasons and explanations for individual address choices. This enabled the study participants to elaborate on their assumptions, which in turn can shed light on what address strategies and stylistic, sociocultural considerations motivate linguistic choices made by doctors and patients. A subset of the questions is targeted at the prototypical 
social value of address forms, while another subset makes inquiries about the context-dependent evaluation of diverse situations. ${ }^{3}$

Explorations of informants' beliefs, their metapragmatic reflections about style and social meanings rest on the assumption that speakers are able to exhibit a reflexive attitude to various linguistic constructions and the socio-cultural expectations, processes of style attribution that are inherent in the use of these constructions (cf. Tátrai-Ballagó 2020). In addition, we also assume that such reflections can be elicited by questionnaires inquiring about opinions in the form of open-ended questions (Bednarek 2011). Accordingly, we took speakers' beliefs and folk categories as a point of departure for studying social meanings and stylistic qualities associated with tetszik. In the present paper, informants' reflections about usage, social meanings, and style are referred to as evaluations.

The data collected in this way do not offer a comprehensive, representative picture of how frequently tetszik is used in doctor-patient communication and how its functions are evaluated by discourse participants. However, the arguments and evaluations supplied by informants do create an opportunity for discerning the main strategies associated with the social meaning of tetszik.

\section{The sociolinguistic attributes of using tetszik}

In Hungarian, not only is there a distinction between T- and V-forms but rather there are several different ways to express V. The construction involving tetszik often complements some of these $\mathrm{V}$-forms to heighten a sense of politeness. However, if it is used in order to avoid V-pronouns, it can also occur independently as a form of V-address. V-forms are highly varied in informal communication, but none of the variants have a general enough scope or neutral social and stylistic value.

According to previous sociolinguistic and pragmatic results (Hollós 1975; Domonkosi 2002, 2010, 2017; Koutny 2004; Dömötör 2005), the use of the tetszik + infinitive structure characterizes various social relationships as a basic expression of politeness. First, it is the most important means of address by children towards adults. Second, it appears as a typical form of address in close but non-equal relationships with a considerable age gap between the interlocutors. Lastly, it expresses politeness in requests (including requests for information) and expressions of interest. The most important variable that governs its usage is the age of the addressee. Which individual functions are at play varies greatly with the agegroups of the speakers (Domonkosi 2002, Domonkosi-Kuna 2015b).

3 For the questions under study here which we used to elicit answers from doctors, see the Appendix of the present paper. Doctors and patients were asked to respond to the same questions in modified versions, which had been adjusted to the situation. 
The construction with tetszik is more salient than other V-forms due to its lengthy and elaborate nature. Moreover, apart from child-adult relations and situations with a large age gap between speakers, it is also more marked in most scenarios.

\section{The role of tetszik in doctor-patient communication}

The relation between doctor and patient is basically asymmetric and hierarchical due to the doctor's wealth of knowledge and the social status attached to this profession. Therefore, a meeting between doctor and patient is predominantly a formal occasion. Yet, more and more psychological, linguistic, and medical studies suggest that trust, empathy, and cooperation are crucial components at the core of the healing relationship. This requires a sort of affinity, which originates mostly in the doctor's social and linguistic behaviour, i.e. it works in a "top-down" manner.

There is a change taking place in healthcare: while previously an authoritarian (doctor- and illness-centred) behaviour used to be prevalent, today both doctors and patients tend to prefer partner-like (patient-centred and relationship-centred) care (cf. Stewart-Brown et al. 2003, Heritage-Maynard 2006, Warren et. al. 2006, Beach 2013, Bigi 2016, Kuna 2016). One goal of our presentation here is to show how tetszik participates in the construal of doctor-patient relationships.

In what follows, we present the results of the questionnaire study with a focus on social meaning. Our analysis follows qualitative principles rather than statistical ones, so we focus on the main areas and tendencies. The findings are presented in the following order: 1) results on the usage of tetszik, 2) doctors' and patients' opinions on social meaning and stylistic value, and 3) strategies underlying the use of tetszik.

\subsection{The use of tetszik in doctor-patient communication}

From the answers to questions 4, 6, 7, and 8 (see the Appendix), it can be observed that doctors tend to identify more situations in which they would choose or prefer to use tetszik. Figure 1, showing answers given to Question 4, makes this preference clear: $90 \%$ of the doctors would use tetszik and only $10 \%$ would not, while only $30 \%$ of the patients would prefer tetszik and $70 \%$ would not.

Informants' replies to this question suggest that an important variable defining preference for tetszik is clearly age, more specifically the addressee's old age and/or a large age gap between the interlocutors. The other (and less important) one is the addressee's gender. This is supported by the answers and explanations received in response to Question 7. 83\% of the doctors prefer tetszik, especially in the case of elderly and female patients. By contrast, the answers of patient participants suggest that there is no situation in which they would have a preference for tetszik in their 
communication with a doctor: $63 \%$ says that there is no situation in which they would prefer tetszik, and $80 \%$ tries to avoid it expressly.

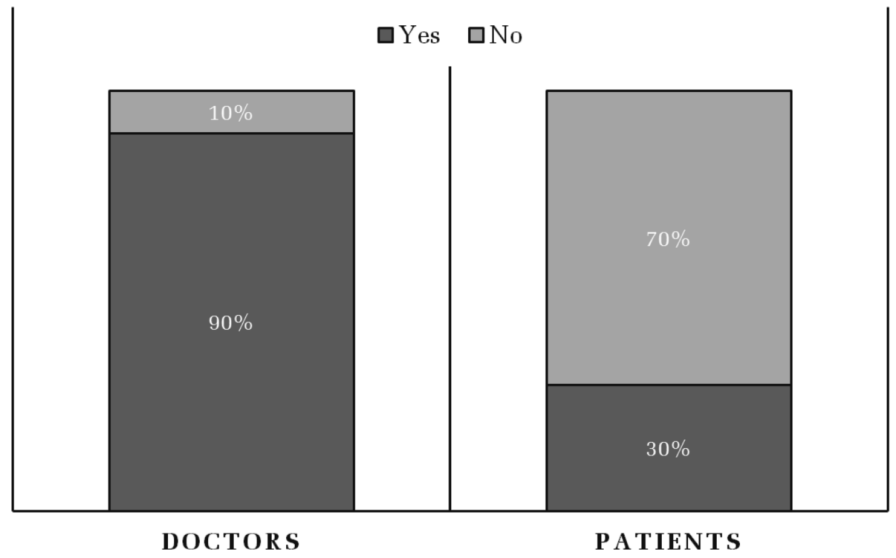

Figure 1. The use of tetszik according to the doctors' and the patients' selfreflection

\subsection{Social and stylistic values of tetszik}

Our participants shared a variety of opinions about social meanings at work in the use of tetszik. These opinions reflect spontaneous style attributions and evaluations of the use of this politeness marker. Questions 12 and 17 were open-ended (see the Appendix); hence, they reflect the participants' spontaneous evaluations. The most common evaluations included közvetlen 'direct', kedves 'kind', tiszteletteljes 'respectful', and barátságos 'friendly' or their combinations. A typical answer to Question 12 involves two or three adjectives circumscribing the style and mood associated with this form; additionally, special values/usages/circumstances may be specified. For example:

(1) tisztelettudó, barátságos, közvetlen, de sokszor lehet udvariaskodó, hízelgó, akár nevetséges is 'respectful, friendly, direct; but it can be a mannerism, flattering or even ridiculous';

(2) szívélyes megszólítás idôsek számára 'a cordial way of addressing the elderly;'

(3) közelséget enged, ami az orvos-beteg kapcsolatban fontos 'it allows for closeness [between interlocutors], which is important in doctor-patient relationships'.

With certain participants, typical combinations of evaluative phrases emerged, referring to respect, directness, and kindness. These co-occurrences highlight the fact that speech situations cannot be modelled along a linear axis; instead, their construal is best categorized from various perspectives. 
One of these perspectives can be identified as the positioning of the discourse partner in the foreground or in the background, which is manifested in the evaluations respectful/disrespectful and polite/impolite. Another aspect evidenced in the descriptions is the issue of hierarchy between discourse partners, manifested in such evaluations as alárendelödő 'self-subordinating', önlekicsinylő 'selfdeprecating', or megalázkodó/lekezelő 'self-degrading/patronizing'. Some participants elaborated on the same theme: Azt sugallja, hogy nem egyenrangú a két fél. 'It suggests that the two parties are not equal.' The notion of subordination in the interpretation of addressing forms also suggests that the traditionally relevant subdomains of solidarity vs. power, status-oriented vs. solidarity-oriented are at play here. The third aspect is the expression of social distance between the interlocutors, manifested in the evaluations direct vs. remote. This may be closely connected to the second aspect; however, its scope is broader since social distance is shaped not only by differences in hierarchical status but also by other differences and similarities (cf. Svennevig 1999: 34-35). The above aspects are complemented by a fourth one: that of the expression of an emotional relation to the discourse partner, as revealed by evaluations such as kedves/rideg 'kind vs. cold' and barátságos/ barátságtalan 'friendly vs. unfriendly'. When social distance and an emotional relation are both referred to, this can either increase or decrease perceived distance; however, the two functions (and their evaluations by informants) are still different. The expression of emotional relations might also be interpreted as an indicator of involvement. As a marker of attention and empathy towards the patient, it can be separated from the marking of social distance.

These aspects do not have a parallel distribution in the usage of address forms; so, for example, a polite address will not necessarily be kind and informal. In our view, attribute clusters can account for the complex social indexical values of various Hungarian V-forms efficiently. Using tetszik is prototypically respectful yet informal and kind. In certain cases, it can contribute to the construal of the speech situation, and it can highlight the interlocutors' social status.

\subsection{Strategies with tetszik}

Based on observations and the data gained from questionnaires, we can conclude that tetszik is used predominantly by doctors in their communication with patients. This contradicts the assumption that it is a generic, especially a polite and softening form in this situation (cf. Domonkosi 2002: 205). Based on data about proportions of use as well as explanations offered by informants, various strategies can be identified, which depend on the participants' roles as doctors or patients and on the relationship between discourse partners. 


\subsubsection{Doctors' strategies of using tetszik}

According to the doctors' self-reflection, a majority of them tend to use tetszik. There are diverse strategies regarding the use or avoidance of tetszik. One of the most typical strategies is that by opting for tetszik forms doctors attempt to create a more informal situation. According to their self-reflections, they mostly use tetszik while addressing elderly patients. This usage corresponds to a generic sociolinguistic role of tetszik mentioned above - namely that it is used in unequal but rather intimate relations when there is a huge age gap between the speakers (Domonkosi 2002, 2010; Domonkosi-Kuna 2015a, 2015b; Koutny 2004).

As the perceived social value of tetszik is more informal and kinder than that of other V-forms, it indicates the speaker's intention to express an emotional attitude to the discourse partner. Consequently, since this linguistic form is perceived as more informal, it implies a strategy of empathy, involvement, and decreasing social distance:

(4) Az idôsebbek esetében közvetlenebbnek, személyesebbnek, mégis tisztelettudóbbnak tartom. 'In the case of addressing the elderly, I consider it more direct, more personal, and still more respectful.'

(5) Személyesebbnek gondolom egy idôsebb beteg esetén, talán a bizalom megszerzése miatt. 'When addressing an elderly patient, I consider it more personal, maybe because it conveys the building of trust.'

(6) Idôsebbekhez szólva; kedvesebb, közvetlenebb, nem olyan merev. 'For addressing the elderly; it is kinder, more direct, less rigid.'

In self-reflections about this use of tetszik, the role of age and gender is usually, and characteristically, emphatic. However, personal observations suggest that in addressing younger patients tetszik is also quite frequent, which is one reason why we embarked on a questionnaire study.

Using tetszik also activates the notion of hierarchy in the way the situation is construed. Previous research (Domonkosi 2002, 2010; Koutny 2004) and the self-reflections of speakers associated the use of tetszik prototypically with selfsubordination. In this case, however, it emerges in the utterances of doctors, who are hierarchically of higher status than the other party. By using a self-subordinating structure from a clearly superordinate position, they attempt to bridge the social gap between partners. Therefore, using tetszik can decrease social distance; yet it should not be treated as if it exhibited solidarity. Situations involving solidarity are characterized by mutually used forms (Brown-Gilman 1960, Agha 2007), while in this scenario the forms remain asymmetric, being used only by one party.

Use of this strategy can also imply that the speaker is aware of the addressee's subordinate status. 
(7) Nagyon, nagyon ritkán [használom] és csak nehezen mozgó időseknél. '[I use it] very, very rarely, and only when addressing elderly people who can hardly move.'

(8) Esetleg a nagyon idôs, leépült nóbetegeknél, de senki másnál. Possibly with very old, broken-down female patients, but with no one else.'

Despite its prototypically self-subordinating role, the use of tetszik is considered patronizing by doctors, who attach to it the function of forcing the addressee into $a$ subordinate position. This may be due to the aforementioned asymmetrical nature of the expression's usage. The right to initiate the decreasing of social distance lies with the person of superior status.

(9) Kerülendônek [tartom], mert hangsúlyozza a beteg alárendeltségét '[I think it is] to be avoided because it highlights the patient's subordinate status.'

(10) (...) mintha nem tekintené az orvos egyenrangú félnek a beteget. 'as if the doctor didn't regard the patient as an equal partner.'

Another possible reason for the avoidance of tetszik may lie in the patient's behaviour. The process of construing the situation is continuous and dynamic; it depends on both speakers and their negotiations simultaneously. Accordingly, the avoidance of using tetszik may be a reactive strategy prompted by the patient's often insulting behaviour or their attempts to reduce distance.

(11) támadó, lekezelő magatartású személynél, mert határozottabb, távolságtartóbb így 'to an aggressive or condescending person because it is more authoritative and distant';

(12) öntelt, bizalmaskodó betegek, magas múveltségú betegek; előbbinél a távolságtartást jelzem, utóbbinál nem akarok „anyáskodni” 'to self-important, excessively friendly or highly educated patients - to the former, I want to indicate our distance, for the latter, I do not want to appear overbearing'.

In explanations offered by a few doctors, there is a less flexible strategy taking shape. In particular, they try to use the form generally, attributing undifferentiated politeness to it. Similar generalizing tendencies can be found in the deliberate avoidance of tetszik, which usually owes most to the personal preferences of the doctor.

Using tetszik can be incorporated in a peculiar strategy, mostly directed at young patients; in these situations, it becomes ironic. Due to a shift in perspective, the linguistic construal of the situation is no longer adequate in this context. Since the most crucial variable in the use of tetszik is age, its employment with young patients is not adequate, which enables the speaker to use it ironically. Ironic usage is a prerogative of the superordinate partner, which explains why it can be offensive through its emphasis on hierarchy, and why it is often conjoined with lecturing. 
(13) [a tetszik stílusa] (...) gyakran kioktató '[the style of using tetszik] is often condescending'.

(14) Van amikor a tetszikelés mögött egy nyomatékosító, pedagógiai jellegú tartalom van. 'Sometimes, there is an affirmative and pedagogical motivation behind the use of tetszik.'

According to our data and observations, diverse functions and strategies in the use of tetszik can result in a considerable mismatch between intended and perceived effects. For instance, a form that is intended to be polite may be interpreted as offensive. These differences in negotiations can be traced back to the fact that using tetszik accentuates the age of the addressee, whereas in other cases it simply expresses heightened politeness. By using tetszik, the speaker puts the addressee in a position in which the latter's age becomes prominent at a conscious level. The often perceived offensive effect of the form can also be a consequence of the same phenomenon. According to our data from the questionnaires, the most often mentioned condition of using tetszik is age. However, our observations in real-life situations suggest that there need not be any age gap between speakers.

\subsubsection{Patients' strategies of using tetszik}

Our data indicate that there is a much larger number of speakers among patients who avoid using tetszik altogether. This tendency is most often attributed to a sense of childishness, unnaturalness, and awkwardness associated with its use.

(15) Kerülöm, mert nagyon tanár-diák-os viszonyra emlékeztet. (...) 38 évesen nem beszél így az ember. 'I avoid it because it reminds me of a teacher-student relationship. [...] At the age of 38, you don't talk like this.'

(16) [kerülöm]. Gyermeteg. '[I avoid it.] It is childish.'

Avoidance, according to a few participants, is bound up with doctor-patient communication and their rejection of construing certain roles therein. These patients usually do not create a subordinate position for themselves and avoid being socially exposed or being spoken to in a mock informal tone:

(17) Az orvossal egyenrangú felek vagyunk - ezt a tetszik/tessék nem tükrözi. 'We are equal partners with the doctor - this is not reflected by tetszik/tessék.'

(18) A túlságosan „udvariaskodó” forma hierarchiára utal. 'By being excessively polite, this form indicates hierarchy.'

Even though avoidance seems to be a very strong tendency among patients, typical and conventional usage can override this intention and fear of hierarchy. 
Two very typical sociolinguistic functions of tetszik can be seen even in these situations (Domonkosi 2002: 205). One such function is that a large age gap between speakers or the age and gender of the addressee can motivate the use of tetszik (Domonkosi-Kuna 2015b).

(19) Csak a háziorvosomnál [használom], mert idősebb, nö orvos és engem tegez, illetve 20 éve hozzá járok. '[I use it] only with my GP, and the reason is that she is older, she is a female doctor, she uses T-forms to address me, and she has been my GP for 20 years.'

(20) Csak rendkívül idôs orvossal szemben érezném helyénvalónak. 'I would only consider it appropriate when talking to a very old doctor.'

The other, less frequent sociolinguistic function of using tetszik is explained by specific speech acts that require elevated attention; for example, requests or asking for favours.

(21) Szívességkérés vagy az általánostól eltérô szolgáltatás igénylése esetén. Udvariasabbnak érzem ezt a formát. 'When asking for favours or something uncustomary. I think this form is more polite.'

(22) A kérés nyomatékositása miatt [használom]. '[I use it] for adding weight to a request.'

\section{Conclusions}

According to the data, the most frequent social values associated with tetszik are as follows: közvetlen 'informal', kedves 'kind', barátságos 'friendly', udvarias 'polite', and tiszteletteljes 'respectful'. There are frequent references to age, gender, and social status in the participants' explanations. Using tetszik can thus be described as prototypically respectful but informal and kind; a form whose use takes into account the discourse partners' age, gender, and social status. It is more informal and kinder than other V-forms; yet it is also less conventional. As one of our participants stated, "it is polite; and it's complicated". Accordingly, social values vary greatly and can be downright contradictory.

As we have demonstrated, the stereotypical social meaning of tetszik can be described only in the context of a speaker's strategy. These strategies differ greatly between doctors and patients. On the part of doctors, the most typical function of using tetszik is to reduce social distance. This is in line with the trend that in the communicative behaviour of doctors an increasing number of linguistic devices appear that serve to decrease distance even as doctor-patient relations are necessarily hierarchical in character (Heritage-Maynard 2006, Domonkosi-Kuna 
2015a, Bigi 2016, Heritage 2019). By contrast, among patients, avoiding the form for the sake of avoiding self-subordination is widespread. It is noteworthy in doctors' strategies that from a superordinate position this self-subordinating form becomes a device of reducing social distance.

In our study, it also became apparent that using tetszik can play various roles in the construal of the speech situation and not only along the formal vs. informal axis. Prominent factors include the positioning of the addressee in the foreground or background, hierarchy (power vs. solidarity), social distance, and emotional attitude.

\section{References}

Agha, Asif 2007. Language and social relations. Cambridge: Cambridge University Press.

Bartha, Csilla-Hámori, Ágnes. 2010. Stílus a szociolingvisztikában, stílus a diskurzusban. Nyelvi variabilitás és társas jelentések konstruálása a szociolingvisztika „harmadik hullámában” [Style in sociolinguistics, style in discourse: Linguistic variability and the construction of social meaning in the “third wave” of sociolinguistics]. Magyar Nyelvór 134(3): 298-321.

Beach, Wayne A. 2013. Introduction. In: Beach, Wayne A. (ed.), Handbook of patient-provider interactions. New York: Oxford University Press. 1-18.

Bednarek, Monika. 2011. Approaching the data of pragmatics. In: Bublitz, WolframNorrick, Neal (eds.), Foundations of pragmatics. Berlin-Boston: Walter de Gruyter. 537-559.

Bigi, Sarah 2016. Communicating (with) care. A linguistic approach to the study of doctor-patient interactions. Amsterdam-Berlin-Washington: IOS.

Brown, Roger-Gilman, Albert. 1960. The pronouns of power and solidarity. In: Sebeok, Thomas A. (ed.), Style in language. Cambridge: MIT Press. 253-276.

Clyne, Michael-Norrby, Catrin-Warren, Jane. 2009. Language and human relations. Styles of address in contemporary language. Cambridge: Cambridge University Press.

Coupland, Nikolas. 2007. Style: Language variation and identity. (Key topics in linguistics). Cambridge-New York: Cambridge University Press.

Csiszárik, Katalin-Domonkosi, Ágnes 2018. A gyógyító-beteg viszonylat megszólítási változatai egy mozgásszervi rehabilitációs osztály gyakorlatközösségében [Address form variants in healer-patient interactions in the practice community of a musculoskeletal rehabilitation ward]. Acta Universitas de Carolo Eszterházy Nominatae, Sectio Linguistica Hungarica (44): 109-128.

Domonkosi, Ágnes. 2002. Megszólítások és beszédpartnerre utaló elemek nyelvhasználatunkban [Address forms and elements referring to the interlocutor 
in Hungarian language use]. A DE Magyar Nyelvtudományi Intézetének Kiadványai. Vol. 79. Debrecen.

2010. Variability in Hungarian address forms. Acta Linguistica Hungarica 57(1): $29-52$.

2018. The socio-cultural values of Hungarian V-forms of address. Eruditio Educatio 13(3): 61-72.

Domonkosi, Ágnes-Kuna, Ágnes. 2015a. A tetszikelés szociokulturális értéke. A tetszikelő kapcsolattartás szerepe az orvos-beteg kommunikációban [Sociocultural values of a form of address: The role of tetszik in doctor-patient communication]. Magyar Nyelvő́r 139(1): 39-63.

2015b. „Hanyadikra tetszik menni?” - A kor szerepe a tetszikelés használatában [The role of age in the use of the tetszik construction]. In: Balázs, Géza-Veszelszki, Ágnes (eds.), Generációk nyelve. Budapest: ELTE Mai Magyar Nyelvi Tanszék Inter - Magyar Szemiotikai Társaság. 273-285.

Dömötör, Adrienn 2005. Tegezés/nemtegezés, köszönés, megszólítás a családban [T/V, greetings, and address within the family]. Magyar Nyelvór 129(4): 299-318.

Eckert, Penelope-Rickford, John R. (eds.), 2001. Style and sociolinguistic variation. Cambridge: Cambridge University Press.

Ervin-Tripp, Susan. 1972. On sociolinguistic rules: Alternation and co-occurrence. In: Gumperz, J. John-Hymes, Dell (eds.), Directions in sociolinguistics: The ethnography of communication. New York: Holt, Rinehart and Winston. 213-250. Heritage, John. 2019. The expression of authority in US primary care: Offering diagnoses and recommending treatment. Paper presented at the Georgetown University Round Table 2018. Approaches to discourse (Ms).

Heritage, John-Maynard, Douglas (eds.). 2006. Communication in medical care: Interaction between primary care physicians and patients. Cambridge: Cambridge University Press.

Hollós, Marida 1975. Comprehension and use of social rules in pronoun selection by Hungarian children. In: Ervin-Tripp, Susan-Mitchell-Kernan, Claudia (eds.), Child discourse. New York: Academic Press. 211-223.

Kuna, Ágnes. 2016. Person deixis and self-representation in medical discourse: Usage patterns of first person deictic elements in communication by doctors. Jezyk, Komunikacja, Informacja/Language, Communication, Information 11: 99-121.

2020. Változás az orvos-beteg kommunikációban. Változó szemlélet, módszer és gyakorlat [Change in doctor-patient communication. Changing models, methods, and practice]. Magyar Nyelvốr 144(3) (forthcoming).

Kuna, Ágnes-Hámori, Ágnes. 2019. „Hallgatom, mi a panasz?” A metapragmatikai reflexiók szerepei és mintázatai az orvos-beteg interakciókban ["I'm listening, what is the problem?" On the roles and patterns of metapragmatic reflections in doctor-patient interactions]. In: Laczkó, Krisztina-Tátrai, Szilárd (eds.), 
Kontextualizáció és metapragmatikai tudatosság. Budapest: Eötvös Collegium. 260-283.

Kuna, Ágnes-Kaló, Zsuzsanna. 2014. Az orvos-beteg kommunikáció a családorvosi gyakorlatban [Doctor-patient communication in primary care]. In: Veszelszki, Ágnes-Lengyel, Klára (eds.), Tudomány, technolektus, terminológia. A tudományok, szakmák nyelve. Budapest: Éghajlat. 117-130.

Norrby, Catrin et al. 2015. Interpersonal relationships in medical consultations. Comparing Sweden Swedish and Finland Swedish address practices. Journal of Pragmatics (84): 121-138.

Norrby, Catrin-Wide, Camilla (eds.), 2015. Address practice as social action: European perspectives. London, UK: Palgrave Macmillan.

Schilling-Estes, Natalie 2004. Investigating stylistic variation. In: Chambers, J. K.-Trudgill, Peter-Schilling-Estes, Natalie (eds.), The handbook of language variation and change. Malden-Oxford: Blackwell. 375-402.

Stewart, Moira A. et al. (eds.). 2003. Patient-centered medicine: Transforming the clinical method. $2^{\text {nd }}$ ed. Oxon: Radcliffe Medical Press Ltd.

Svennevig, Jan. 1999. Getting acquainted in conversation. A study of initial interactions. Amsterdam-Philadelphia: Benjamins.

Tátrai, Szilárd-Ballagó, Júlia. 2020. A stílustulajdonítás szociokulturális szituáltsága. Funkcionális kognitív pragmatikai megközelítés [Socio-cultural situatedness in style attribution. A functional cognitive pragmatic approach]. Magyar Nyelvốr 144(1): 1-41.

Warren, Ed (ed.). 2006. B.A.R.D. in the practice. A guide for family doctors to consult efficiently, effectively and happily. Oxford: Radcliff Publishing.

Wide, Camilla et al. 2019. Variation in address practices across languages and nations: A comparative study of doctors' use of address forms in medical consultations in Sweden and Finland. Pragmatics (29):595-621.

\section{Web sources}

Koutny, Ilona 2004. A 3. út: a tetszikelés [The $3^{\text {rd }}$ way: Using tetszik]. VII. Nemzetközi Magyar Nyelvészeti Kongresszus [Presentation at the $7^{\text {th }}$ International Hungarian Linguistics Congress]. Budapest. http://www.nytud.hu/NMNyK/eloadas/koutnyho.rtf (downloaded on: 01.22.2019). 


\section{Appendix}

Questions Nr. 4, 6, 7, 8, 12, 17 - questions related to tetszik in the doctors' questionnaire. For the entire questionnaire, see Domonkosi \& Kuna 2015a: 54-62.

4. Do you use the structures tetszik/tessék in your practice when talking to patients? (E.g. Mióta tetszik szedni ezt a vérnyomáscsökkentôt? 'Since when have you been taking these blood pressure pills?' Please underline your answer.

a) Yes, I do.

b) No, I don't.

Why?

6. For whom do you think "tetszik" is an appropriate address during your consulting hours or in a hospital (patients, colleagues, relatives of patients, etc.)? Why?

7. Are there any situations when you prefer saying "tetszik/tessék" in your communication with patients? Please underline your answer.

a) Yes, there are.

In which situations and talking to what kind of people?

Why?

b) No, there are not.

Why?

8. Are there any situations when you consciously avoid using the structures tetszik/tessék in your communication with patients? Please underline your answer.

a) Yes, there are.

In what situations and talking to what kind of people?

Why?

b) No, there are not.

Why?

12. How would you evaluate the tetszik structures?

17. What do you think about the situations below, concerning the linguistic behaviour of the doctor, and the appropriateness and style of the used expression?

- A 35-year-old male doctor is talking to a 25 -year-old female patient during consulting hours.

Nagyon csúnyán tetszik köhögni. 'You are coughing really badly.'

- A 40-year-old female doctor is talking to a 30-year-old male patient.

Miért nem urológushoz tetszett ezzel a problémával fordulni? 'Why haven’t you turned to a urologist with this problem?'

- A 45-year-old male doctor is talking to a 20 -year-old female patient.

Miért nem tetszett hamarabb jönni, ha egy hónapja fel van fázva? 'Why haven't you come earlier if you have already been sick for a month?' 
- A 32-year old female doctor is talking to a 52-year-old female patient. Köhög, és rögtön el is tetszett kezdeni kezelni magát antibiotikummal?! 'You have a cough, and you immediately started treating yourself with antibiotics?'

- A 58-year-old male doctor is talking to a 25-year-old female patient.

Nagyon le tetszett fogyni, mi történt?'You've lost a lot of weight, what happened?' 